\title{
Reconstruction of palaeoecological changes in Lake Lebsko on the basis diatom analysis (the southern Baltic coast, Poland)
}

\author{
Agata Staszak-Piekarska, Monika Rzodkiewicz \\ Institute of Geoecology and Geoinformation, Adam Mickiewicz University in Poznań, Poland; agata.staszak@amu.edu.pl
}

\begin{abstract}
This study focuses on diatom assemblages occurring in core Łeb1 of Late-glacial and Holocene deposits from Lake Lebsko, off the southern coast of the Baltic Sea. Diatom-inferred environmental characteristics, e.g., water level, water salinity (conductivity), trophic status and $\mathrm{pH}$, from the Holocene are presented. In the sediments from the early Boreal/early Atlantic period, an increase in the participation of brackish-freshwater species is observed, as well as increased numbers of Chaetoceros spores in the samples. The Atlantic sediments of Lake Lebsko mirror conditions typical of the Littorina Sea phase during the development of the Baltic Sea (from c. 7,500 BP to c. 5,000 BP). However, communities of that period dominated by fresh-brackish water species suggest the relatively low salinity of the waters. The presence of isolated frustules of Terpsinoë americana and other typically marine species, e.g., Mastogloia smithii, and the occurrence of silts with Cardium shell detritus point to the Littorina transgression and the functioning of a lagoon within the area of present-day Lake Łebsko. During Subboreal occurrence, a higher number of brackish-freshwater diatoms corresponds to an increase in the water level of the Baltic Sea (approximately 3,000 ${ }^{14} \mathrm{C} \mathrm{BP}$ ). Changes in diatom community structure imply a close relationship with the climate controlled eustatic rise of ocean level and the consequent Littorina transgression, as with other southern Baltic Sea localities.
\end{abstract}

Key words: coastal lakes, diatom communities, palaeoreconstructions, Gardno-Łeba Lowland

\section{Introduction}

Paleoecological research based on the analysis of diatom flora dates back to the beginning of the 19th century. The analysis of fossil diatom flora is commonly used for the reconstruction conditions and changes in past aquatic environments. This is due to the fact that diatoms are excellent bioindicators, i.e., organisms that are sensitive towards environmental conditions of environmental changeability and quickly react to changes in their habitat, as well as being widespread. Identifying the ecological preferences of selected diatom species enables the performance of qualitative analyses of changes in environmental conditions (Kawecka, Eloranta 1994).

Water salinity level constitutes an important factor in the development of diatom assemblages, which makes diatomological analysis one of the basic methods applied for determination of environmental changes in coastal lakes. Diatom analysis is widely used in the studies of paleoecological transformations of both aquatic habitats and areas currently covered by land. This method enables the tracking of changes occurring with time in selected ecosystems (Bogaczewicz-Adamczak 1990). In Poland, diatom analysis was used for paleoreconstructions of
Lake Sarbsko (Przybyłowska-Lange 1981, Woszczyk et al. 2008, 2010, 2014), Lake Dołgie Wielkie (Mazurek et al. 2008, Lutyńska 2008a), Lake Gardno (Bogaczewicz-Adamczak 1977, Bogaczewicz-Adamczak, Miotk 1985, Lutyńska 2008b, Lutyńska, Rotnicki 2009) and Lake Jamno (Przybyłowska-Lange 1979), among others. Zawadz$\mathrm{ka}$ et al. (2008) reported that the extent of Lake Lebsko ran for approximately $1400 \mathrm{~m}$ from the present shoreline.

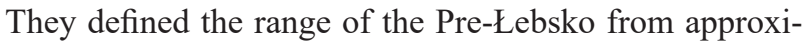
mately 10000 years ago through seismo-acoustic and bathymetric profile interpretation, geological research, and palynological analyses. Pollen and diatomological analysis confirmed that Pre-Łebsko gyttjas were formed from the Younger Dryas to the Boreal period. The sediments were formed in a cold, fresh-water reservoir (Zawadzka et al. 2005, 2008).

The first study of the sediments of Lake Łebsko was conducted by Wojciechowski (1995). His research, based on lithological and malacological analyses of sediments supplemented by radiocarbon dating, showed several stages in the development of the lake. The oldest biogenic series, dated at $9,700 \pm 110$ years BP, was formed by peat. An analogous stratum was found in the area of the barrier, and its age was estimated at 9,840 \pm 110 years BP (Przyby- 
łowska-Lange 1979, Wojciechowski 1995). The analysis of the peat coming from the southern part of Lake Łebsko suggests that the beginning of lagoon-lake sedimentation occurred at approximately 7,100 \pm 70 years BP. This date indicates a relationship between the expansion of the area covered by the lake and the Littorina transgression. The aim of this study was to reconstruct the paleoenvironmental history of Lake Łebsko during the Holocene period.

\section{Study site}

Lake Łebsko is located within the morphogenetic region of a coastal lowland belt. This area (Fig. 1) is characterized by the presence of various postglacial forms, including moraine uplands, terminal and ground moraines, small ice-marginal valleys, accumulation plains, as well as forms related to the formation of the bed and shores of the Baltic Sea (Rotnicki, Borówka 1995, Gilewska 1999). The northern shores of Lake Łebsko can be described as having an accumulative nature (Bogacki 2005).

The bottom of Łebsko is heavily silted, which results from its moderately flow-through nature. With regard to its origin, Lake Łebsko is classified as a coastal lake separated from the sea by a spit (Bajkiewicz-Grabowska 2005). The material filling the bottom of the lake is brought in by the following rivers: Łeba, Pustynka, and Wysoka, as well as the channels and ditches connected with the lake. The shallowing of Łebsko is further intensified by reed rushes, which cause the surface of the lake to retract (Piotrowska 1997). Lake Łebsko is subject to the influence of storm winds and strong waving of the Baltic Sea. The so-called "backwaters" in the mouth of the Leba River cause salt water to pour into the lake. Storms may cause water level variations and salinity changes in the lake. The bottom of the lake is rich in biogenic sediments (Piotrowska 1997).

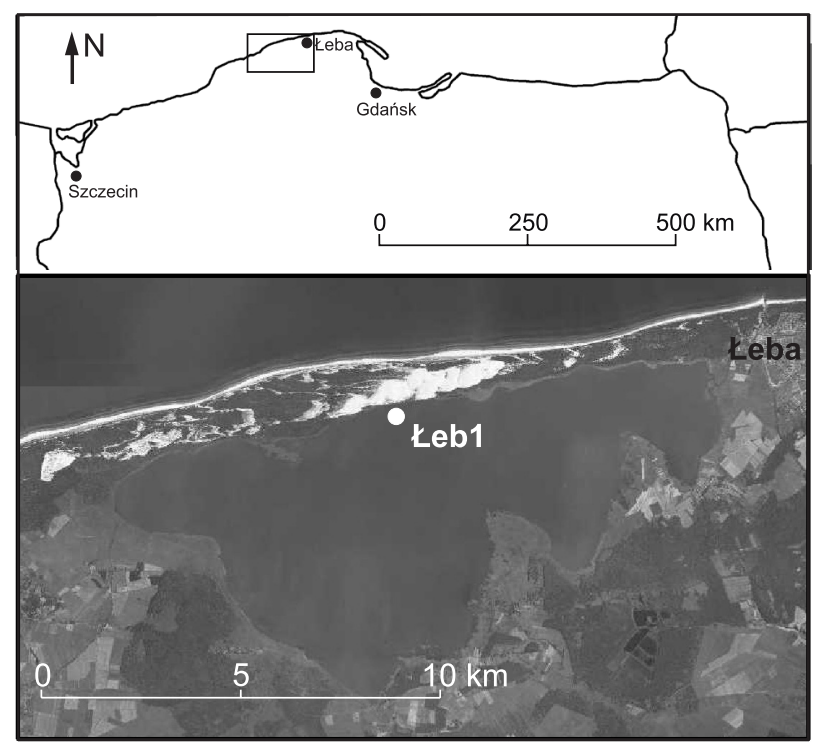

Fig. 1. Location of the study site and the location of the point from which the core was extracted $\left(54^{\circ} 44^{\prime} 27.5^{\prime \prime} \mathrm{N}\right.$, $\left.17^{\circ} 24^{\prime} 04.8^{\prime \prime} \mathrm{E}\right)$

\section{Development history of the South Baltic}

During the last 14,000 years, the range of the South Baltic has been subject to change. Its evolution was strictly associated with climate warming in the Holocene and late Glacial. In the Gardno phase of glaciation, the Baltic Sea was completely covered in ice (Uścinowicz 1995). The slow withdrawal of the continental glacier from Central Europe, lasting thousands of years, caused the evolution and development of the coastline and water range of the Baltic in its southern part (Fig. 2).

\section{Materials and methods}

The material for the diatomological studies was taken from the Łeb1 core sediments. The core was acquired in 2006 in the southeastern part of Lake Łebsko (Fig. 1). The location of the point from which the core was extracted was established on the basis of the research by Wojciechowski (1995), who established the highest thickness of lake sediments near the barrier. The depth of the lake in the extraction point was 1.9 meters. The length of the core was $882 \mathrm{~cm}$.

The sediments found in the Leb1 core included gyttjas, sands, and silt. Sandy sediments, occurring at a depth of $882-846 \mathrm{~cm}$, were of biogenic origin. They were represented by dark gray sands, muddy sands, and fine silt sands containing plant macro-remains. Sandy gyttja (gray and olive), turning into dark-olive, was found at the depth of 846-700 cm. Beneath the layer of gyttja, the presence of sandy silt with the addition of Cardium was revealed. From a depth of $500 \mathrm{~cm}$ to the top of the $\mathrm{Leb} 1 \mathrm{core}$, gyttjas of various colors were found with different levels of Cardium fauna debris. These included beige and darkbeige gyttja, beige-gray gyttja, and olive gyttja.

\section{Diatom analysis}

Samples for diatomological analyses were taken every 5 $\mathrm{cm}$ or less, depending on the lithological changes in the sediments. Laboratory treatment of sediments and microscope slides were prepared according to the standard methods proposed by Battarbee (1986). Calcium carbonate was removed by adding $10 \% \mathrm{HCl}$. The samples were treated with $30 \% \mathrm{H}_{2} \mathrm{O}_{2}$ and boiled on a hot plate (until the reaction was completed) to digest all of the organic matter. After several washings with distilled water, a few drops of diatom suspension were dried on a coverglass. Permanent microscope slides were mounted in Naphrax. In each slide, up to 500 diatom valves were counted. Chaetoceros spores were also counted.

Diatom flora was identified on the basis of the following works: Denys (1991/2), van Dam et al. (1994), Witkowski (1994), Lange-Bertalot, Metzeltin (1996), Witkowski et al. (2000), Krammer (2002), Krammer, Lange-Bertalot (2008a, b, 2010, 2011), and Hofmann et al. (2011). Ecological groups of diatoms were determined 


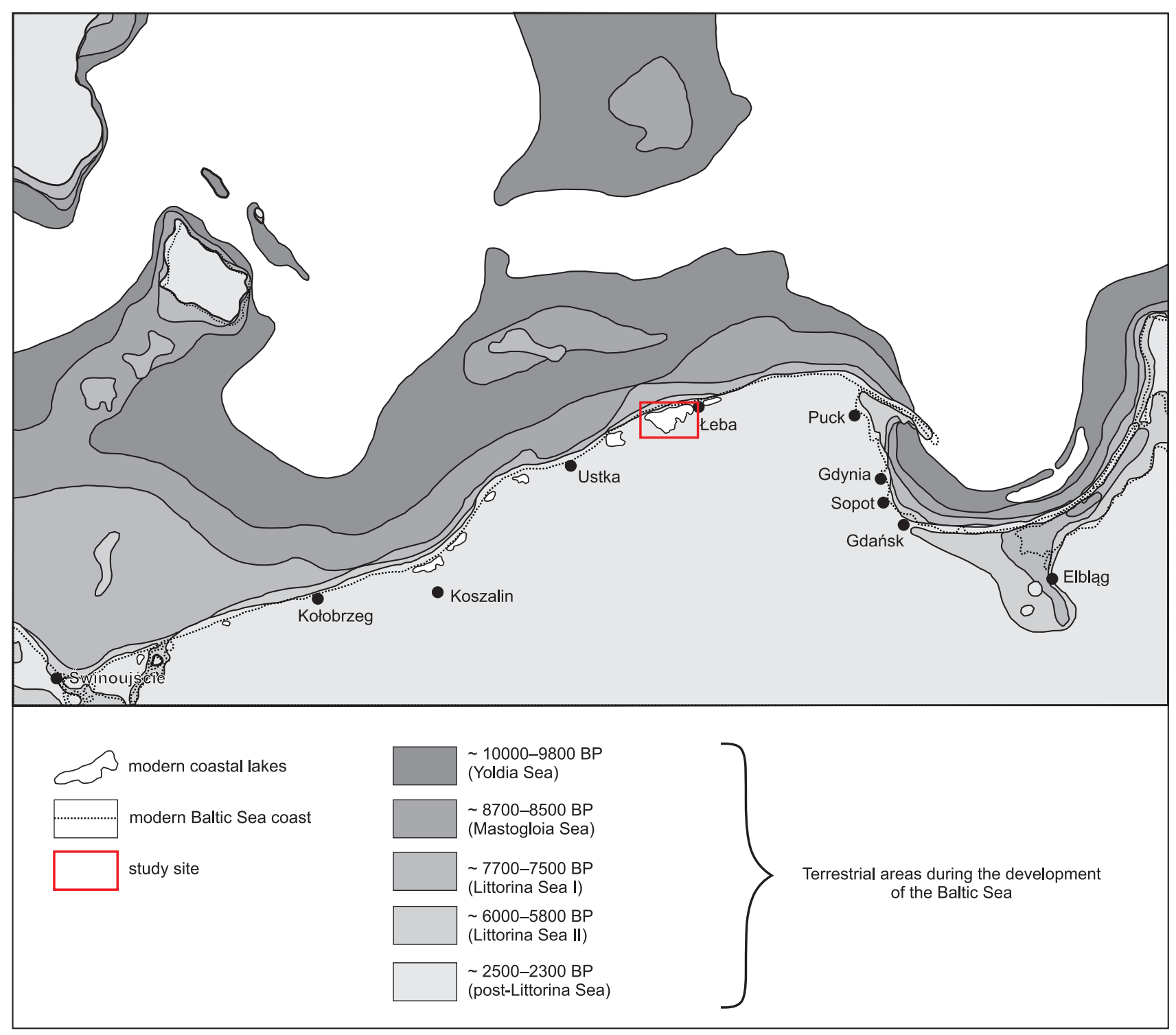

Fig. 2. Changes of the range of the Southern Baltic in the Holocene and late Glacial (Uścinowicz 1995, changed)

by means of the OMNIDIA 4.2 software (Lecointe et al., 1993, 1999). Diagrams showing the percentages of ecological group and dominant species were constructed with the Tilia software (Grimm 1990). The diatom assemblage zones (DAZ) were distinguished by means of Tilia dendrograms, which involve a sum of least squares after being transformed with the square root.

\section{Sediment dating}

Five samples were selected after macroscopic recognition of the lithology of the Łeb1 core and radiocarbon analysis

Table 1. Radiocarbon $\mathrm{C}^{14}$ dates from Lake Łebsko

\begin{tabular}{cccc}
\hline Depth $(\mathrm{cm})$ & Material & ${ }^{14} \mathrm{C}$ age & Laboratory code \\
\hline 90 & Gyttja & $2,890 \pm 40 \mathrm{BP}$ & Poz-43557 \\
460 & Gyttja & $4,240 \pm 35 \mathrm{BP}$ & Poz-43558 \\
520 & Cardium shells & $5,530 \pm 35 \mathrm{BP}$ & Poz-43559 \\
650 & Cardium shells & $6,200 \pm 35 \mathrm{BP}$ & Poz-43560 \\
850 & Brackish silt & $9,360 \pm 50 \mathrm{BP}$ & Poz-43562 \\
\hline
\end{tabular}

in the Poznań Radiocarbon Laboratory (Table 1). The dating results showed that the sediments collected from this water body may contain records of the development of the Baltic from the Mastogloia Sea phase (8,700-8,500 years BP) or even the end of the Yoldia Sea phase 10,000-9,800 years BP) (Uścinowicz 1995) up to modern times.

\section{Results}

A total of 259 diatom taxa were identified in the sediment core. The diatom assemblages from the entire core were rich and very well preserved. However, broken valves were also recorded.

On the basis of the changes in species composition and the associated changes between ecological groups of diatoms, seven diatom phases (DAZ), DAZ I to DAZ VII, were identified. The following ecological spectra were taken into consideration: lifeform, salinity (Fig. 3), pH, and trophic state (Fig. 4). The DAZ I diatom zone (from 


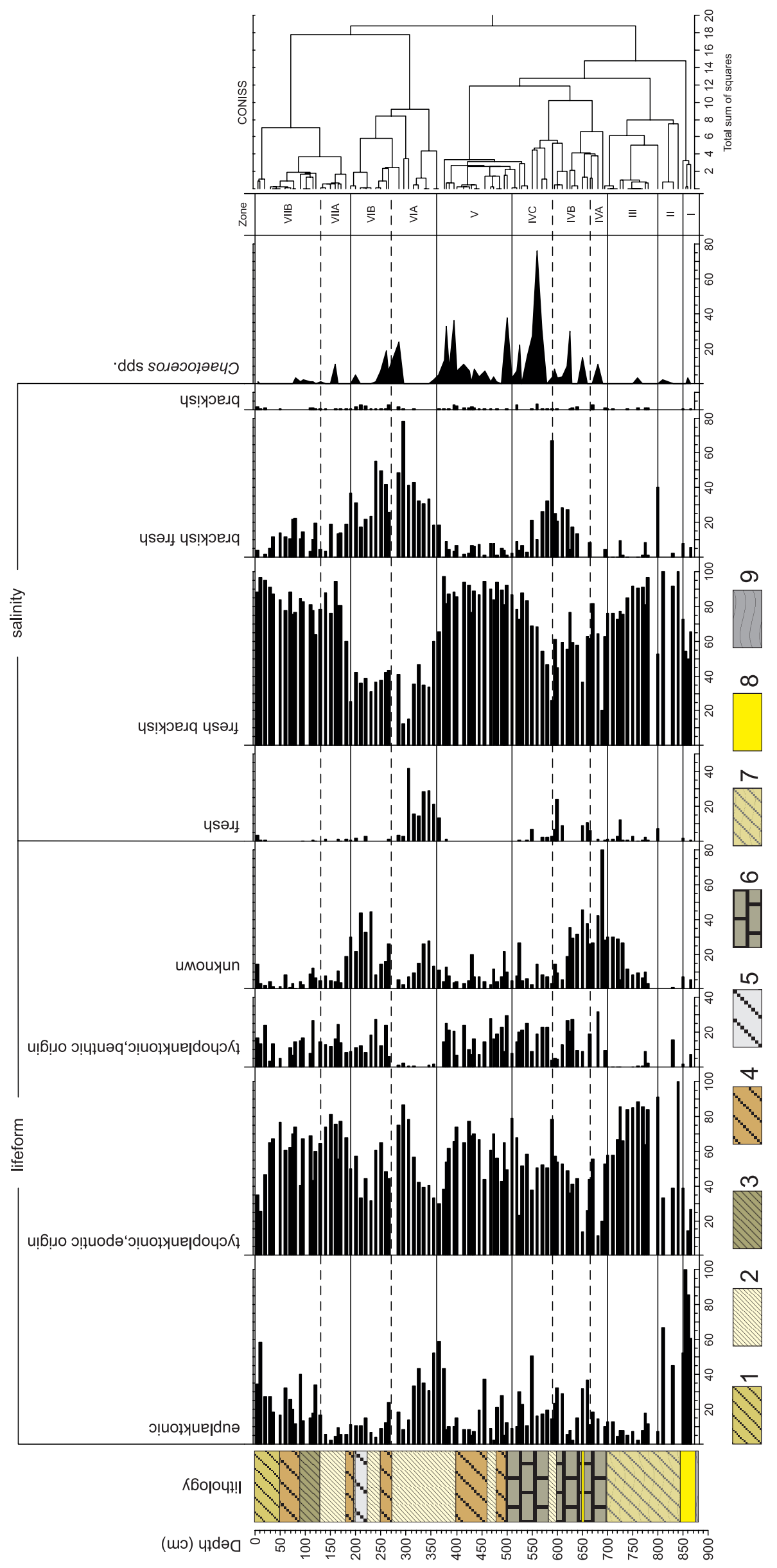




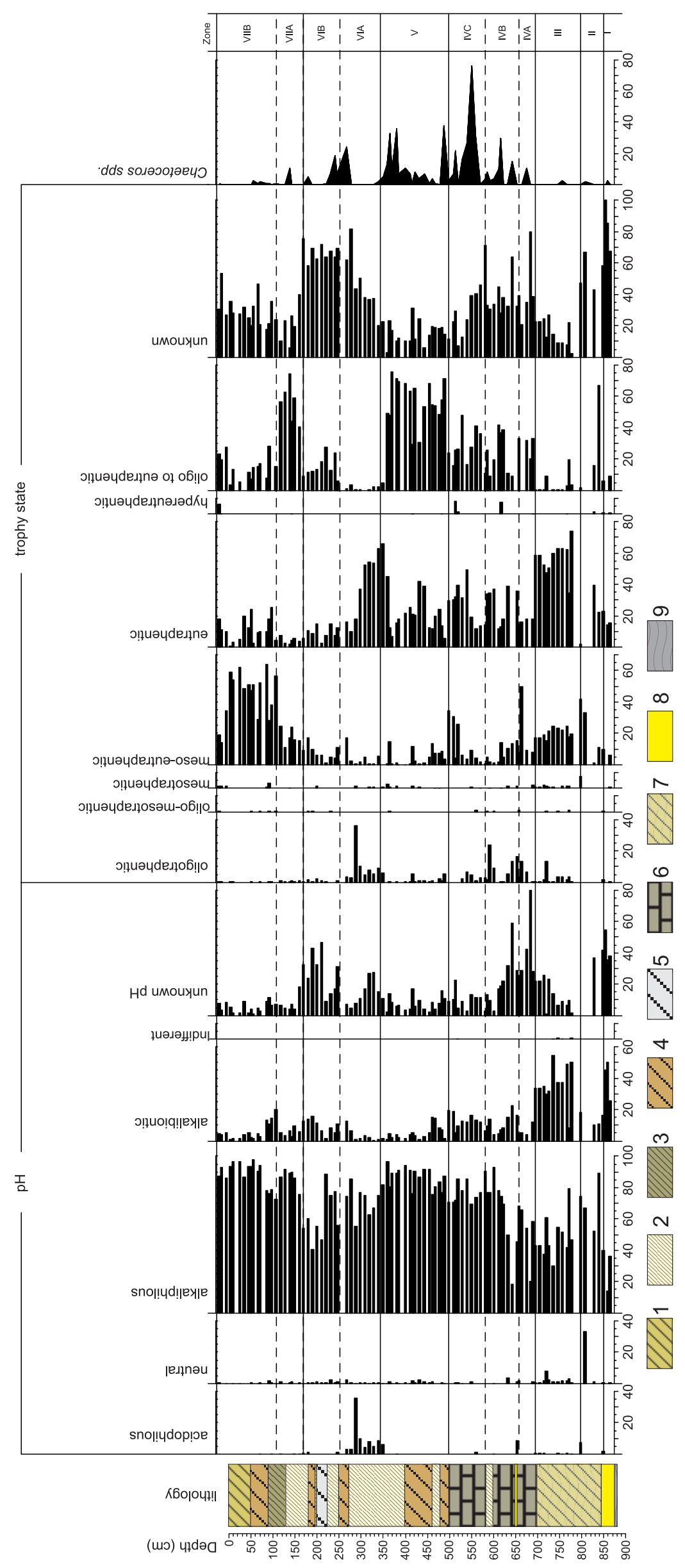


$882 \mathrm{~cm}$ to $850 \mathrm{~cm}$ ) comprises the oldest bottom sediments, which are constituted by sand and silt sand. In the material collected from this part, only few diatom species were identified, and their numbers were very low. In accordance with the boundaries of the Holocene chronozones proposed by Mangerud (1974), the age of the sediments is 9,360 \pm 50 BP. This indicates the Preboreal period, which was characterized by cold and dry climate. The sediments of DAZ II (between $850 \mathrm{~cm}$ and $800 \mathrm{~cm}$ ) comprise olive, sandy gyttja. This zone was dominated by tychoplanktonic diatoms, as well as by euplanktonic diatoms. Tychoplanktonic species originating from benthos occurred only at $830 \mathrm{~cm}$. In terms of salinity, the DAZ II zone shows very strong domination of fresh-brackish water diatoms, represented by Staurosira martyi, Epithemia frickei, Staurosira binodis, and Amphora pediculus, which were accompanied by brackish-freshwater Pseudostaurosira subsalina (up to $40 \%$ of the community). DAZ II was dominated by alkaliphilic species. The bottom part of DAZ II was dominated by oligo- to eutraphentic and eutraphentic species, whereas mezo- eutraphentic taxa made up over 30\% of the total abundance in the upper part. The olive, sandy gyttja constitute sediments of DAZ III $(800 \mathrm{~cm}$ to 700 $\mathrm{cm})$. In comparison with DAZ II, the zone is characterized by a significant increase of tychoplankton originating from epiphytes. The group of fresh-brackish water species was strongly dominant. Alkaliphiles and alkalibionts were the most common groups. DAZ III exhibits strong dominance of eutraphentic species with moderate participation of meso-eutraphentic species. The sediments of this diatom phase are dominated by fresh-brackish species: Cocconeis placentula var. lineata, Epitemia adnata, E. sorex, and Rhopalodia gibba. A slight increase in the relative abundance of brackish-freshwater and brackish species, e.g., Melosira undulata, occurs at the top of DAZ III.

In DAZ IV, three sub-zones were distinguished: DAZ IVA, DAZ IVB, and DAZ IVC. Sub-zone DAZ IVA includes silts from the depth between 700 and $665 \mathrm{~cm}$. In this sub-zone, the taxa are represented by tychoplanktonic species of periphytic and benthic origin. This sub-zone is dominated by fresh-brackish water diatoms (Staurosirella pinnata, Staurosira construens, Pseudostaurosira brevistriata, Epithemia adnata, and Aulacoseira granulata), but the brackish waters species Pseudostaurosiropsis geocollegarum is also present. The dominant $\mathrm{pH}$ group is alkaliphilous, whereas this sublevel is characterized by the occurrence of meso-eutraphentic, eutraphentic, and oligo- to eutraphentic species in terms of trophic preferences. Sediment of the sub-zone DAZ IVB from the depth interval of $665-590 \mathrm{~cm}$ and including silt sand, silt, and beige gyttja were dated. The sediments from the depth of $650 \mathrm{~cm}$ were dated to $6,200 \pm 35 \mathrm{BP}$, indicating the Atlantic sedimentation, which is characterized by warm and humid climate. With respect to habitat, an increase in the participation of tychoplankton occurred, especially of epiphytic origin. Fresh-brackish water species are still dominant, e.g., Staurosirella pinnata, Pseudostaurosira brevistriata, and Aulacoseira granulata. In the top of this sub-zone, the abundance of brackish-freshwater and freshwater species increases (e.g., Pseudostaurosira subsalina - even up to $60 \%$ of the community). A high number of Cheatoceros spores is observed at the depth of $640 \mathrm{~cm}$. In comparison with subphase DAZ IVA, an increase in alkaliphilic species and a decrease in alkalibiontic is observed. The numbers of oligo- to eutraphentic and eutraphentic taxa are the highest. Hypereutraphents, taxa preferring hypertrophic environments, were also found at $630 \mathrm{~cm}(10 \%$ of the community). Single frustules of Terpsinoë americana were identified at a depth of $630 \mathrm{~cm}$ with the use of SEM. DAZ IVC comprises the series of silty sediments from $590 \mathrm{~cm}$ to $510 \mathrm{~cm}$. A sample for radiocarbon dating was taken at $520 \mathrm{~cm}$. The result of the dating was 5,530 \pm 35 $\mathrm{BP}$, which pointed to the Atlantic period. This sub-zone is dominated by tychoplankton, e.g., Aulacoseira alpigena and Ellerbeckia arenaria. Plankton constituted 20-40\% of the community (Aulacoseira ambiqua, A. granulata). In sub-zone DAZ IVC, an increase in the fresh-brackish water diatoms is observed, with a simultaneous decrease in the participation of brackish-freshwater species. Fresh and brackish water forms reach low abundance. This subzone contains Chaetoceros spores (up to $20 \%$ ). The phase is dominated by alkaliphilous species, which are accompanied by alkalibiontic species (10-20\% of the community). The discussed sub-zone exhibits increased participation of eutraphentic, meso-eutraphentic, and oligo- to eutrophentic species. In terms of species, the numbers of the following increased: Amphora pediculus, Aulacoseira granulata, Epithemia adnata, Pseudostaurosira brevistriata, Staurosira construens and Staurosirella pinnata (fresh-brackish water).

DAZ V was established between $510 \mathrm{~cm}$ and $360 \mathrm{~cm}$. This diatom phase is characterized by the presence of silt sediments, olive-beige gyttja, and beige gyttja. The sediment from the depth of $460 \mathrm{~cm}$ was dated to $4,240 \pm 35 \mathrm{BP}$, which points to the Subboreal period. This diatom zone is characterized by the dominance of tychoplankton of periphytic origin (from $40 \%$ to $70 \%$ ) as well as by low participation of plankton and tychoplankton of benthic origin. A decrease in the participation of tychoplankton of epiphytic origin and an increase in euplankton can be observed in the top of DAZ V. The abundance of fresh-brackish forms is characterized by very high participation (from $80 \%$ to $100 \%$ ). This phase is dominated by alkaliphilic species, accompanied by low abundance of alkalibiontic and a complete lack of acidophilous and indifferent species. DAZ V is dominated by oligo- to eutraphentic species, with low participation of eutraphentic and meso-eutraphentic species. The samples contain a small number of Chaetoceros spores. This phase is characterized by strong dominance of Pseudostaurosira brevistriata and Staurosirella pinnata (fresh-brackish). Brackish-freshwater species (Pseudostaurosira subsalina and Cyclotella meneghiniana) exhibited low participation in this group. Brackish taxa were represented by Pseudostaurosiropsis geocollegarum. Few frustules of the Terpsinoë americana 
species were identified in the Łeb1/90 sample at a depth of $456 \mathrm{~cm}$.

Diatom zone VI (360-190 cm) was divided into two sub-zones: DAZ VIA (beige gyttja) and DAZ VIB (olive-beige gyttja, beige gyttja, gray gyttja). Sub-zone DAZ VIA is characterized by a decrease in the participation of species classified as plankton from periphyton and a simultaneous increase in the participation of typically planktonic species, which were most numerous at the bottom of the sub-zone. The discussed sub-zone contained a low abundance of tychoplankton from benthos. In terms of salinity, subphase DAZ VIA exhibits a decrease in the participation of freshwater-brackish diatoms and an increase in the participation of brackish-freshwater and typically freshwater species. Sub-zone DAZ VIA is characterized by the presence of freshwater species: Aulacoseira alpigena and Fragilaria alpestris. DAZ VIA is also characterized by the lack of brackish water diatoms and low participation of fresh-brackish water diatoms (with the exception of Aulacoseira ambigua and A. granulata). With regard to $\mathrm{pH}$, in comparison with the previous diatom phase, DAZ VIA is characterized by relatively low participation of alkaliphilous species. However, the presence of acidophilic species was revealed in this subzone. As far as trophic state is concerned, the discussed sub-zone is characterized by decreasing participation of eutraphentic species and very low participation of oligotraphentic and meso-eutraphentic species. Sub-zone DAZ VIB includes the depths between $270 \mathrm{~cm}$ and $190 \mathrm{~cm}$. This sub-zone is characterized by a decrease in plankton, a small decrease in the participation of tychoplankton of epiphytic origin, and an increase in tychoplankton of benthic origin. The minimum abundance in this DAZ is attained by freshwater forms. Fresh-brackish water species constitute from $20 \%$ to $40 \%$ of the species in the assemblage. The bottom of sub-zone DAZ VIB showed an increase in brackish-freshwater diatoms, the participation of which goes down with decreasing depth. The sub-zone is characterized by the occurrence of a low abundance of brackish water species. Only a few Chaetoceros spores were found. DAZ VIB is characterized by the dominance of alkaliphilic species, the participation of which decreases towards of the top of the subphase, with a simultaneous increase in alkalibionts. The sub-zone exhibits low participation of meso-eutraphentic, eutraphentic, and oligo- to eutraphentic species and a very low number of Chaetoceros spores. The brackish-freshwater species Pseudostaurosira subsalina is clearly dominant. In sub-zone DAZ VIB, the group of fresh-brackish water diatoms is represented by Staurosirella pinnata. The brackish water species of Pseudostaurosiropsis geocollegarum is also found.

Diatom zone VII, including the depths between 190 $\mathrm{cm}$ and $0 \mathrm{~cm}$, was divided into two sub-zones: DAZ VIIA and DAZ VIIB. DAZ VIIA includes the sediments between $190 \mathrm{~cm}$ and $130 \mathrm{~cm}$, represented by beige gyttja. This sub-zone is characterized by an increased relative abundance of tychoplankton originating from epiphytes and very low participation of planktonic taxa and tychoplankton of benthic origin. Dominant in the sediments of this zone are fresh-brackish water diatoms, i.e., Pseudostaurosira brevistriata, Staurosira binodis, Staurosirella pinnata, or Fragilaria inflata var. istvanffyi, with low participation of brackish-freshwater species. High participation of alkaliphilous and low participation of alkalibiontics was recorded. Clear dominance of oligo- to eutraphentic is also visible, with low participation of meso-eutraphentic and very low participation of eutraphentic. The discussed sub-zone contained a minute number of Chaetoceros spores. The group of brackish-freshwater diatoms is represented by Pseudostaurosira subsalina. Subzone DAZ VIIB includes the youngest $(130-0 \mathrm{~cm})$ sediments of the Łeb1 core (olive gyttja, olive-beige gyttja, dark-olive gyttja). A sample (Łeb1/18) was taken at $90 \mathrm{~cm}$ and dated at 2,890 $\pm 40 \mathrm{BP}$, which points to the close of the Subboreal period, a time associated with slow warming of the climate (the beginning of the Subatlantic is dated at 2,500 ${ }^{14} \mathrm{C}$ ). The bottom of this subphase exhibits clear dominance of tychoplankton from epiphytic origin, the participation of which decreases towards the top of this sub-zone, with a simultaneous increase in the numbers of planktonic species and tychoplankton of benthic origin. Sub-zone DAZ VIIB is characterized by a clear increase in the participation of fresh-brackish water diatoms (up to $100 \%$ ), including Staurosira binodis, Staurosirella pinnata and Fragilaria inflata var. istvanffyi (the participation of the latter increases from the bottom towards the roof of the subphase), with a simultaneous decrease in the numbers of brackish-freshwater diatoms. Pseudostaurosira subsalina (a brackish-freshwater species) is also abundant in this subphase. The bottom of the core contains the following brackish taxa: Cocconeis scutellum and Pseudostaurosiropsis geocollegarum. The discussed subphase is characterized by strong dominance of alkaliphilic species and low participation of alkalibionts. The top of DAZ VIIB exhibits a decrease in mesotraphentic species in favor of oligo- to eutraphentic species.

\section{Discussion}

The results of the diatomological analysis enable the reconstruction of the development of Lake Lebsko. The low diatom frustule count at the bottom of the core could have been caused by poor preservation in sandy sediments. The strong dominance of fresh-brackish water diatoms in the deepest sediments of the Łeb1 core points to the low salinity of the water body in that period. With regard to $\mathrm{pH}$, alkaliphilic and alkalibiontic species were the most common ones in the sediments from the Subboreal and Boreal periods.

In the sediments from the close of the Boreal/early Atlantic period $(6,200 \pm 35 \mathrm{BP})$, an increase in the participation of brackish-freshwater species can be observed, as well as increased numbers of Chaetoceros spores in the samples. Witak (1998) showed that their presence in 
sediments may be an indicator of high water productivity. These spores constitute a common element of phytoplankton in brackish and salt water (Witak 1998). The increase in the relative abundance of brackish-freshwater species at 650 to $570 \mathrm{~cm}$ corresponds to the increase in the level of the Baltic Sea, which took place at approximately $6,500{ }^{14} \mathrm{C}$ BP according to the curve of South Baltic level changes by Rotnicki (1999). These results correspond to the works of Kowalczyk et al. (1999). On the basis of a diatomological analysis of sediments from the Gotland Deep, the first Littorina transgression was dated at c. 7,000 years BP. It is also important to mention that Wojciechowski $(1994,1995)$ documented the existence of a lagoon in the area of Lake Lebsko, appearing at c. 6,500 years BP. The Atlantic sediments were dominated by tychoplankton of periphytic origin. The Atlantic sediments of Lake Łebsko fit into the Littorina Sea phase of the development of the Baltic, which lasted from c. 7,500 BP to c. 5,000 BP. The above-mentioned Littorina transgression took place within that period, which was accompanied by a gradually increasing salinity of the Baltic Sea, resulting from its eventual connection with the ocean (Uścinowicz 2003). However, fresh-brackish water species exhibit strong domination in the sediments of that period, which may point to the relatively low salinity of the waters surrounding northern Poland. In terms of $\mathrm{pH}$, almost $100 \%$ of all species are alkaliphilous taxa. Trophic conditions are characterized by the dominance of oligoto eutraphentic species occurring in a wide spectrum of trophic tolerance.

The overlying sediments, the sedimentation of which took place during the Subboreal (between DAZ V and DAZ VI), point to an increase in the fertility of this water body. An episode of increased numbers of acidobiontic species were found in the sediments of diatom phase DAZ VIA, but their participation in the overall number of taxa reached $10-30 \%$. The sediments of the Subboreal exhibit an increase in the count of brackish-freshwater diatoms, which correspond to an increase in the water level of the Baltic Sea (Fig. 4), estimated at c. 3,000 ${ }^{14} \mathrm{C}$ BP (Rotnicki 1999). In terms of $\mathrm{pH}$, the sediments of the late Subboreal and Subatlantic are characterized by the dominance of alkaliphilic species, whereas the trophic index points to the dominance of meso-eutrophic species. Several species preferring hypereutrophic conditions appear at the roof of the core. They may constitute an indicator of human activity because hypereutrophic taxa are usually found in hypertrophic environments, which are rich in humic substances. With regard to salinity, the bottom section of the core is dominated by freshwater-brackish diatoms, whereas it is dominated by plankton from periphyton in terms of habitat category.

The least significant environmental changes were found in terms of habitat category and $\mathrm{pH}$. More visible diversification can be seen when examining the changes in ecological groups in terms of preferred salinity or trophic conditions of the water body. The presence of Chaetoceros spores in Atlantic sediments, especially in DAZ IV, is also worth emphasizing. Increases in the numbers of persistent spores are associated with increasing amounts of nutrients in seawater. The production of vegetative cells is stimulated by better access to nourishment (Witak 1998). Increases in the numbers of Chaetoceros spores are considered to be indicative of high water productivity (Witak 1998). It is also important to mention the presence of Terpsinö americana in the samples from the Atlantic and Subboreal periods. Although the presence of this species is justified at a depth of $630 \mathrm{~cm}$ by the age of the sediments (c. $6,200 \pm 35 \mathrm{BP}$ ), the climatic conditions, and the phase of the development of the Baltic Sea (Littorina Sea phase), its occurrence at a depth of $456 \mathrm{~cm}$ cannot be unambiguously explained. Terpsinoe americana is considered to be an index species for the Littorina Sea of the Atlantic period (Bresińska-Burchardt 1972). In 1967, Brodniewicz and Rosa established the sporadic occurrence of this species in in situ sediments of the Littorina Sea period originating from the area of Czołpino. Brodniewicz and Rosa (1967) also identified a probable cause for which the mass growth of $T$. americana stopped. A typical oceanic species, T. americana, was also found in surface sediments of the Gotland Basin in the Baltic Sea (Grönlund 1993). It appears to have grown in the Baltic Litorina Sea during the Holocene climatic optimum (Alhonen et al. 1984, Risberg 1986, Grönlund 1993). According to Witkowski (1991), the surface sediments of Puck Bay suggest that $T$. americana may be a relict component of Atlantic diatom flora (Grönlund 1993)

A decrease in the salinity of the Littorina Sea resulted from the increasing isolation of the Baltic and had direct influence on the degradation of the species. The presence of $T$. americana in sediments from the Subboreal might be explained by the washing out of sea sediments from the coast of the Baltic and sedimentation accompanied by increasing sea-level at that time. At the same time, the transfer of sediments from the area of the sea to the area of the present-day Lake Łebsko may have occurred as a result of storm backwater.

The presence of isolated frustules of T. americana and other typically marine species, e.g., Mastogloia smithii, and the occurrence of silts with Cardium shell detritus may point to the Littorina transgression (Uścinowicz 2003) and the functioning of a lagoon within the area of the present-day Lake Lebsko. Another species characteristic for the Littorina Sea phase is Campylodiscus clypeus. In 1994, in his study of the Gdańsk Bay, Wojciechowski described the period in which this species was present as "clypeus lagoon", constituting one of the phases of the Littorina Sea. In the sediments from the Łeb1 core, the Campylodiscus clypeus species appeared sporadically in the material dated to the Subboreal period. This may also point to the inflow of sea sediments to the area of the present-day Lake Łebsko, resulting from storm backwater or marine transgression. 


\section{Conclusions}

On the basis of the diatomological analysis of the sediments from Lake Lebsko, it is clear that its functioning was dependent on the influence of the nearby Baltic Sea. The Leb1 core sediments point to three phases in the development of Lake Łebsko: marine, lagoon, and lake. However, the diatomological analysis does not directly confirm this hypothesis because of the scarcity of brackish species, even in the bottom section of the core. The results of the reconstruction of salinity change may suggest that the change in salinity was not high in the southern part of the Baltic, even when it was connected with the ocean. The results of the diatomological analysis, especially the analysis of the changes in preferred halobity and diatom community species composition, as well as the analysis of persistent Chaetoceros form count and lithological sediment changeability, may suggest that Lake Łebsko functioned as a lagoon in the Atlantic period. This hypothesis is confirmed by radiocarbon datings. The presence of the relict species of Terpsinoë americana, associated with warm Atlantic climate, and Campylodiscus clypeus in sediments dated to the Subboreal period may lead to the conclusion that seawater poured into the discussed water body, e.g., as a result of storm backwater. The increased participation of meso-eutrophentic and eutrophentic species, as well as the episodic presence of hypereutrophent in the roof of the Łeb1 core, may constitute a premise concerning the trophic changes in Lake Łebsko in the past centuries. These do not, however, constitute direct evidence for the eutrophication of this water body.

Lake Łebsko, as a coastal water body with a connection to the Baltic Sea, characterized by rapid accumulation of sediments, constitutes a rich source of knowledge concerning the changes taking place within the coastal region of the South Baltic.

\section{Acknowledgements}

The research is financially supported by a grant from the National Science Centre (grant no. NN306 064 640). Teresa Mazurek, Michał Woszczyk, Władysław Pawłów, and Artur Rzodkiewicz helped during field work. The laboratory assistance of Małgorzata Schade is greatly appreciated.

\section{References}

Alhonen, P., Heino A., Tynni R., 1984. Ober Vorkommen and Bedeutung von Terpsinoё americana (Bail). Ralfs in den Ablagerungen des Litorinameeres. Bulletin of the Geological Society of Finland 56(1-2): $117-133$

Bajkiewicz-Grabowska E., 2005. Jeziora. In: A.Richling, K.Ostaszewska (eds.), Geografia fizyczna Polski, Wydawnictwo Naukowe PWN, Warszawa: 173-183.

Battarbee R.W., 1986. Diatom analysis. In: B.E. Berglund (ed.), Handbook of Holocene Paleoecology and Paleohydrology: 527-570.
Bogacki M., 2005. Współczesne procesy morfogenetyczne. In: A. Richling, K. Ostaszewska (eds.), Geografia fizyczna Polski, Wydawnictwo Naukowe PWN, Warszawa: 71-81.

Bogaczewicz-Adamczak B., 1977. Analiza okrzemkowa subatlantyckich osadów z rejonu jeziora Gardno. Studia i Materiały Oceanologiczne 19(1): 285-290.

Bogaczewicz-Adamczak B., 1990. Paleolimnologia jezior Borów Tucholskich w świetle badań kopalnych okrzemek. Zeszyty Naukowe Uniwersytetu Gdańskiego: 1-133.

Bogaczewicz-Adamczak B., Miotk G., 1985. Z badań biostratygraficznych nad osadami z rejonu jeziora Gardno. Peribalticum 3: 79-96.

Bresińska-Burchardt L., 1972. Terpsinoë americana (Bail.) Ralfs - kopalna okrzemka na terenie Słowińskiego Parku Narodowego. Badania Fizjograficzne nad Polską Zachodnią ser. B 25: 221-232.

Brodniewicz I., Rosa B., 1967. The boring hole and the fauna at Czołpino, Poland. Baltica 3: 61-86.

Denys L., 1991/2. A check-list of the diatoms in the Holocene deposits of the western Belgian coastal plain with a survey of their apparent ecological requirements. Service Geologique de Belgique 1, 2(246).

Gilewska S., 1999. Rozwój środowiska Polski w trzeciorzędzie. In: L. Starkel (ed.), Geografia Polski. Środowisko przyrodnicze, Wydawnictwo Naukowe PWN, Warszawa: 38-65.

Grimm E.C., 1990. TILIA and TILIA.GRAPH: PC spreadsheet and graphics software for pollen data. INQUA - Commission for the Study of the Holocene, Working-Group on Data-Handling Methods. Newsletter 4: 5-7.

Grönlund T., 1993. Diatoms in surface sediments of the Gotland Basin in the Baltic Sea. Hydrobiologia 269/270: 235-242.

Hofmann G., Werum M., Lange-Beralot H., 2011. Diatommen im Süßwasser-Benthos von Mitteleuropa. ARG Gantner Verlag KG, Königstein.

Kawecka B., Eloranta P., 1994. Zarys ekologii glonów wód słodkich i śródlądowych. PWN Wydawnictwo Naukowe, Warszawa.

Kowalczyk K., Witkowski A., Struck U, 1999. Environmental changes in the Gotland Deep Turing the late-glacial and Holocene as inferred form siliceous microfossils (mainly diatoms) analyses. Quaternary Studies in Poland, Special Issue: 135-145.

Krammer K., 2002. Diatoms of the European Inland Waters and Comparable Habitats. In: H. Lange-Bertalot (ed.), Diatoms of Europe vol. 3, Cymbella.

Krammer K., Lange-Bertalot H., 2008a. Bacillariophyceae 2, Ephitemiaceae, Bacillariaceae, Surirellaceae. In: H. Ettl, J. Gerloff, H. Heyning, D. Mollenhauer (eds.), Süsswasserflora von Mitteleuropa 2. T 2, 4th Edition. Fischer, Stuttgart.

Krammer K., Lange-Bertalot H., 2008b. Bacillariophyceae 3, Centrales, Fragilariaceae, Eunotiaceae. In: H. Ettl, J. Gerloff, H. Heyning, D. Mollenhauer (eds.), Süsswasserflora von Mitteleuropa 2. T3, 3rd Edition. Fischer, Stuttgart.

Krammer K., Lange-Bertalot H., 2010. Bacillariophyceae 1, Naviculaceae. In: H. Ettl, J. Gerloff, H. Heyning, D. Mollenhauer (eds.), Süsswasserflora von Mitteleuropa 2. T 1, 4th Edition. Fischer, Stuttgart.

Krammer K., Lange-Bertalot H., 2011. Bacillariophyceae 4, Achnanthaceae. In: H. Ettl, J. Gerloff, H. Heyning, D. Mollenhauer (eds.), Süsswasserflora von Mitteleuropa 2. T 4, 3rd Edition. Fischer, Stuttgart.

Lange-Bertalot H., Metzeltin D., 1996. Indicators of Oligotrophy. 800 taxa representative of three ecologically distinct lake types. In: $\mathrm{H}$. Lange-Bertalot (ed.), Iconogrphia Diatomologica. Annotated Diatom Micrographs 2.

Lecointe C., Coste M., Prygiel J., 1993. "OMNIDIA": software for taxonomy, calculation of diatom indices and inventories management. Hydrobiologia 269/270: 509-513.

Lecointe C., Coste M., Prygiel J., Ector L., 1999. Le logiciel OMNIDIA version 3, une puissante base de données pour les inventaires de diatomées et pour le calcul des diatomiques européens. Cryptogamie Algologie 20: 132-134.

Lutyńska M., 2008a. Environmental changes in lake Dołgie Wielkie in the light of diatom analysis. Quaestiones Geographiceae 27A/1: 63-68.

Lutyńska M., 2008b. Fazy rozwoju jeziora Gardno na podstawie analizy okrzemkowej i geochemicznej. In: K. Rotnicki, J. Jasiewicz, M. 
Woszczyk (eds.), Holoceńskie przemiany wybrzeży i wód południowego Bałtyku - przyczyny uwarunkowania i skutki, Wydawnictwo Tekst sp. z o.o., Poznań-Bydgoszcz: 35-43.

Lutyńska M., Rotnicki K., 2009. Zapis zmian paleoekologicznych jeziora Gardno na podstawie analizy okrzemkowej. In: A. Kostrzewski, R. Paluszkiewicz (eds.), Geneza, litologia i stratygrafia utworów czwartorzędowych, V, Seria Geografia 88: 281-298.

Mangerud J., Andersen S.T., Berglund B.E., Donner J. 1974. Quaternary stratigraphy of Norden, a proposal for terminology and classification. Boreas 3: 109-126.

Mazurek T., Lutyńska M., Rotnicki K., 2008. Ślady młodoholoceńskich wlewów wód morskich do jeziora Dołgie Wielkie. In: K. Rotnicki, J. Jasiewicz, M. Woszczyk (eds.), Holoceńskie przemiany wybrzeży i wód południowego Bałtyku - przyczyny uwarunkowania i skutki, Wydawnictwo Tekst sp. z o.o., Poznań-Bydgoszcz.

Piotrowska H., 1997. Podstawowe wiadomości o środowisku przyrodniczym In: H. Piotrowska (ed.), Przyroda Słowińskiego Parku Narodowego, Bogucki Wydawnictwo Naukowe, Poznań-Gdańsk: 17-40.

Przybyłowska-Lange W., 1979. Diatoms of lake deposits from the polish Baltic coast II. Lake Jamno. Acta Paleobotanica XX(2): 227-244.

Przybyłowska-Lange W., 1981. Diatoms of the lake deposits from the Polish Baltic Coast. III. Lake Sarbsko. Acta Paleobotanica 21: 145160.

Risberg J., 1986. Terpsinoë americana (Bailey) Ralfs, a rare species in the Baltic fossil diatom flora. In: F. Round (ed.), Proceedings of the 9th International Diatom Symposium 1986. Biopress, Bristol and S. Koeltz, Königstein: 207-218.

Rotnicki K., 1999. Problem holoceńskich transgresji Bałtyku południowego na wybrzeżu środkowym Polski w świetle nowych danych z obszaru Niziny Gardnieńsko-Łebskiej In: R.K. Borówka, Z. Młynarczyk, A. Wojciechowski (eds.), Ewolucja geosystemów nadmorskich południowego Bałtyku: 121-139.

Rotnicki K., Borówka R. K., 1995. The Last Cold Period in the Gardno-Łeba Coastal Plain. In: K. Rotnicki (ed.), Polish Coast: Past, Present and Future. Journal of Coastal Research 22: 225-229.

Uścinowicz S., 1995. Ewolucja Południowego Bałtyku w późnym glacjale i holocenie, 1:500 000 In: J.E. Mojski (ed.), Atlas geologiczny Południowego Bałtyku, Wydawnictwo Kartograficzne Polskiej Agencji Geologicznej S. A., Sopot-Warszawa.

Uścinowicz S., 2003. Jak zmieniał się Bałtyk. Online: http://www. pgi.gov.pl/pl/geologia-morza-i-wybrzeza-uslugi/informacjaprzestrzenna-strefa-brzegu-dna-morskiego/387-historia-baltyku.html $-10.04 .2013$

Van Dam H., Mertens A., Sinkeldam J., 1994. A coded checklist and ecological indicator values of freshwater diatoms from Netherlands. Netherlands Journal of Aquatic Ecology 28: 117-33.

Witak M., 1998. Postglacjalna historia rozwoju wybranych rejonów Zalewu Puckiego w świetle badań kopalnej flory okrzemkowej. Uniwersytet Gdański, Gdynia.
Witkowski A., 1991. An occurrence of living Terpsinoë americana (Bailey) Ralfs in bottom sediments of the Puck Bay (The Southern Baltic Sea), Poland. Diatom Research 6: 413-415.

Witkowski A., 1994. Recent and fossil diatom flora of the Gulf of Gdańsk, Southern Baltic Sea. Bibliotheca Diatomologica 28: 1-313

Witkowski A., Cedro B., Kierzek A., Baranowski D., 2009. Diatoms as a Proxy In reconstructing the Holocene environmental changes in the south-western Baltic Sea: the lower Rega River Valley sedimentary record. Hydrobiologia 631: 155-172.

Witkowski A., Lange-Bertalot H., Metzeltin D., 2000. Diatom flora of marine coasts. Vol.1. In: H. Lange-Bertalot (ed.), Iconographica Diatomologica: Annotated Diatom Micrographs 7.

Wojciechowski A., 1994. Deposits, brackish-water and marine malacofauna of the Holocene age in Lake Łebsko, Gardno-Łeba Coastal Plain. In: K. Rotnicki (ed.), Changes of the Polish Coastal Zone. Guide-Book of the Field Symposium. IGU CCS Symposium on Changes of Coastal Zones, 96-100.

Wojciechowski A., 1995. Holocene deposits and molluscan assemblages in Lake Łebsko, Gardno-Łeba Coastal Plain. In: K. Rotnicki (ed.), Polish Coast: Past, Present and Future. Journal of Coastal Research 22: 236-243.

Woszczyk M., Lutyńska M., Spychalski W., 2008. Zmiany środowiskowe w jeziorze Sarbsko na podstawie badań geochemicznych i diatomologicznych profilu Sa1/2. In: K. Rotnicki, J. Jasiewicz, M. Woszczyk (ed.), Holoceńskie przemiany wybrzeży i wód południowego Bałtyku - przyczyny uwarunkowania i skutki, Wydawnictwo Tekst sp. z o.o., Poznań-Bydgoszcz.

Woszczyk M., Spychalski W., Lutyńska M., Cieśliński R., 2010. Temporal trend in the intensity of subsurface saltwater ingressions to coastal Lake Sarbsko (northern Poland) during the last few decades, IOP Conf. Series: Earth and Environmental Science 9.

Woszczyk M., Tylmann W., Jędrasik J., Szarafin T., Stach F., Skrzypczak J., Lutyńska M., 2014, Recent sedimentation Dynamics In a shallow coastal lake (Lake Sarbsko, northern Poland): driving factors, processes and effects, Marine and Freshwater Research 65 (12): $1102-1115$

Zawadzka E., Miotk-Szpiganowicz G., Krzymińska J., Witak M., 2005. Badania rzeźby dna I analizy biostratygraficzne osadów jeziornych przybrzeża mierzei jeziora Łebsko. In: W. Florek (ed.), Geologia i geomorfologia Pobrzeża i Południowego Bałtyku 6, Wydawnictwo Naukowe Akademii Pomorskiej, Słupsk.

Zawadzka E., Miotk-Szpiganowicz G., Przezdziecki P., 2008. Pra-Łebsko i Pra-Sarbsko - zasięg zbiorników i dynamika ich współczesnych mierzei. In: K. Rotnicki, J. Jasiewicz, M. Woszczyk (eds.), Holoceńskie przemiany wybrzeży i wód Południowego Bałtyku - przyczyny, uwarunkowania i skutki. Wydawnictwo TEKST Sp.z.o.o., PoznańBydgoszcz. 